\title{
Model Systems for Spinocerebellar Ataxias: Lessons Learned About the Pathogenesis
}

\author{
Thorsten Schmidt*\#, Jana Schmidt ${ }^{*}$ and Jeannette Hübener ${ }^{*}$ \\ Eberhard-Karls-University Tuebingen, Medical Genetics
}

Germany

\section{Introduction}

Model systems are important tools for the investigation of pathogenic processes. Especially for diseases with a late onset of symptoms and slow progression, like most spinocerebellar ataxias (SCA), it is time-consuming or even impossible to analyze all aspects of the pathogenesis in humans. Due to the reduced lifespan of model organisms, it is possible to study disease progression in full within a reasonable timeframe and due to the shorter generation time of most model organisms more individuals can be generated and analyzed, thereby strengthening the reliability of data via an increased number of replicates. Detailed studies of the histopathology can only be performed as endpoint analyses in humans, but with the help of an animal model, multiple time points can be analyzed throughout the course of the disease. In addition, model systems allow not only for the reduction of time from idea to results but also reduce the complexity due to their smaller genome sizes, less genes, nonredundant pathways, and a simpler nervous system.

Before using a specific species to model a disease it is of interest to check whether the proteins affected in humans are conserved within the respective model organism in order to increase the probability that binding partners and other keyplayers, involved in the pathogenesis of this disease, are likewise conserved. For those SCA which are caused by polyglutamine (polyQ) expansions, the respective affected genes are conserved in most organisms used as models (Table 1). Especially the proteins affected in SCA2, SCA6 and SCA17 are conserved with high similarity down to even yeast. This is not surprising as the TATA-binding protein (affected in SCA17) or a subunit of a voltage-dependent calcium channel (affected in SCA6) are important proteins for cellular maintenance. Although polyQ repeats are comparatively frequent in drosophila (Alba et al., 2007), only the repeat region of the TATA-binding protein is conserved. For most other non-mammalian model organisms, the respective orthologues are smaller and the polyQ repeats itself or even including the whole surrounding domains are not conserved. For analyses of SCA, various model systems have been employed. From the worm (Caenorhabditis elegans) and the fly (Drosophila melanogaster) all the way to mammals, i.e. the mouse (Mus musculus), model systems have

\footnotetext{
* All three authors contributed equally to this work

\# Corresponding author: Thorsten Schmidt, Ph.D.; University of Tuebingen; Medical Genetics;

Tuebingen; Germany; Email: Thorsten.Schmidt@med.uni-tuebingen.de
} 
made important contributions to the understanding of disease progression and will be important tools for the first line tests of potential treatment strategies.

This review aims to sum up the model systems used for the investigation of SCA and especially focuses on the lessons learned from these models about the pathogenesis of SCA. We also compare commons and differences in the results obtained using these animal models and highlight the species-specific advantages and possible problems associated with the use of this species as a model organism.

\section{Lessons learned from non-mammalian models of SCA}

\subsection{Lessons learned from worm models}

The nematode Caenorhabditis elegans is frequently used as a model organism, primarily because of its anatomic and biochemical simplicity as well as its genetic tractability. The worm genome encodes orthologues for about $65 \%$ of all known human disease genes. Moreover, it allows for easy and rapid establishment of transgenic lines, thus facilitating screening and characterization of human disease-causing mutations in vivo. Overall it is an often used model organism to analyze pathological features of neurodegenerative diseases (Huntington's disease, Parkinson's disease or Alzheimer's disease) (reviewed in Driscoll and Gerstbrein, 2003 and Brignull et al., 2006b). Except for ataxin-7, the worm contains orthologues for all SCA caused by polyQ expansion. Interestingly, for SCA C. elegans strains have only been generated and characterized for SCA2 and SCA3 (Ciosk et al., 2004; Khan et al., 2006; Kiehl et al., 2000; Rodrigues et al., 2007; Teixeira-Castro et al., 2011).

In the field of polyQ diseases (e.g. HD or SCA) the formation of aggregates, and therefore, the transition of polyQ proteins to their toxic forms is not well understood. Due to its transparency, C. elegans is especially suitable to address this question. PolyQ proteins can be attached to a fluorescent protein (e.g. GFP, YFP, CFP) and the dynamics of aggregate formation both within individual cells and over time can be examined throughout the worm lifespan. Transgenic lines can be rapidly generated by feeding C. elegans wildtype strains with genetically transformed bacteria or by microinjection of manipulated DNA into the germline. The worm's life-cycle of about 2 to 3 weeks under suitable living conditions is short. This allows studying the aggregate formation of many different constructs with various polyQ lengths, with or without flanking sequences of the endogenous protein and under control of a wide range of different promoters. When expressed in the body wall muscle of C. elegans, even short polyQ stretches (with less than $40 \mathrm{Qs}$ ) without any flanking sequences from endogenous proteins tend to aggregate in old worms indicating a balance of different factors including repeat length and changes in the cellular protein-folding environment over time (Morley et al., 2002). In neurons, however, the pathogenic threshold turned out to be about 35-40 repeats, which correlates well with the human disease. This means that in comparison with muscle cells, neuronal cells have a higher aggregation threshold (Brignull et al., 2006a). By way of contrast, the analysis of aggregation in the protein context of (full-length) ataxin-3 revealed that only a highly expanded polyQ stretch (Q130) was able to induce the formation of aggregates in the cytoplasm and nucleus of neuronal cells in transgenic C. elegans lines. Non-expanded (Q14, Q17) and even pathological expanded polyQ stretches (Q75, Q91) were diffusely distributed within neurons 


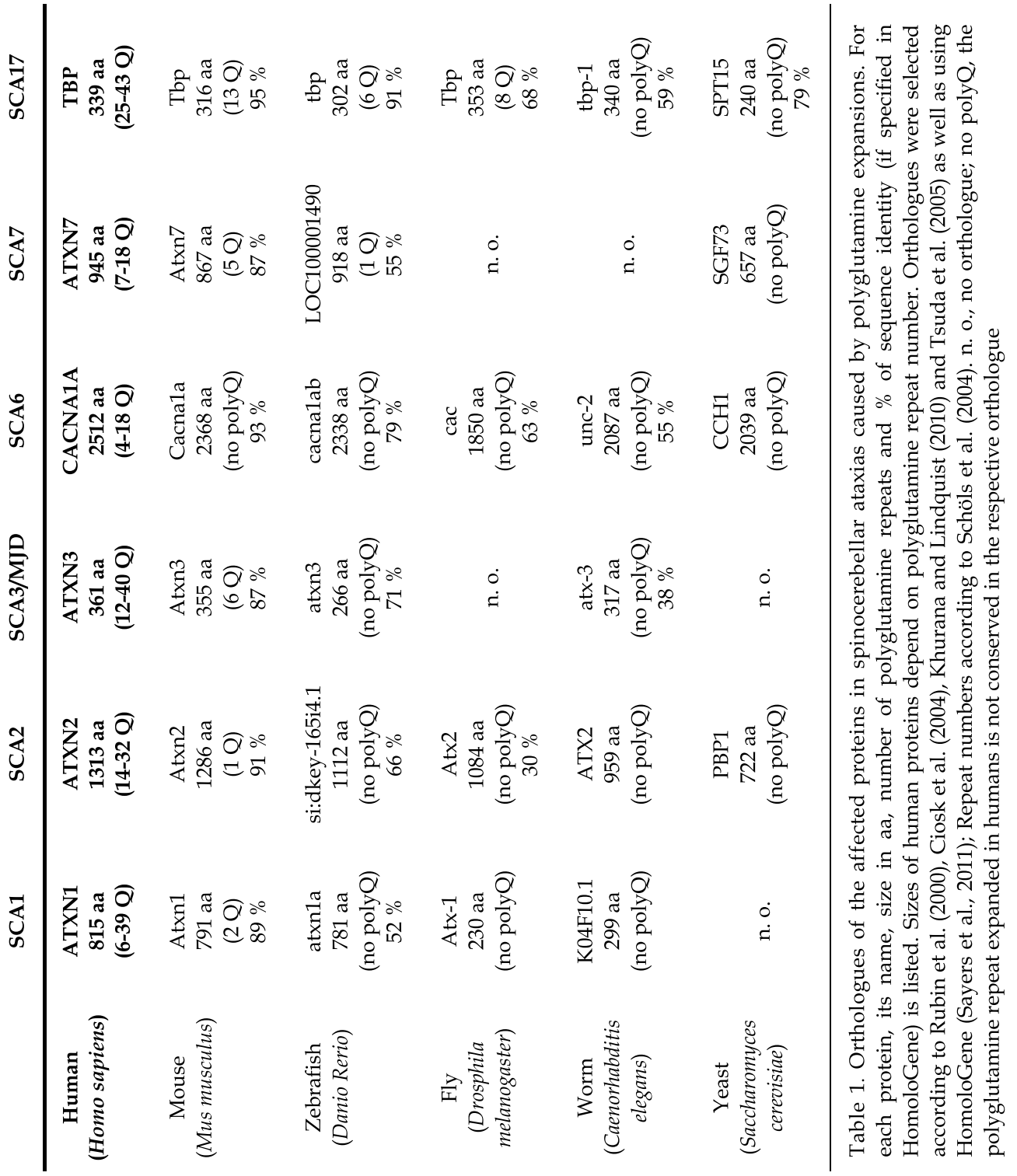


without aggregation (Khan et al., 2006; Teixeira-Castro et al., 2011). In a truncated protein of ataxin-3, however, just 63Q are sufficient for aggregation mainly in the perinuclear region but rarely in the nucleus (Khan et al., 2006). These results are in line with observations made in mouse models, where a truncated form of the polyQ expanded protein induced more aggregates and a more progressive neurological phenotype than the full-length protein (Ikeda et al., 1996).

C. elegans is also a useful organism for studying the normal distribution and function of polyQ proteins both during development and throughout the full lifespan. For example, a SCA2 transgenic model, which expressed the C. elegans orthologue of the human ataxin-2 gene under the control of the endogenous promoter, revealed a strong expression of ataxin-2 in the central nervous system of adult worm, but also allowed the detection of ataxin- 2 even in the early embryo, beginning around the 4-cell stage (Kiehl et al., 2000). Likewise, the expression of the worm orthologue of the human ataxin-3 was strongly detected during the late embryogenesis and during all stages of postnatal development. Interestingly, ataxin-3 was not only detected in the central nervous system (in the neuronal dorsal and ventral cord as well as in neurons of the head and tail) but was also observed in the spermatheca, vulval muscle, hypoderm, coelomocytes and body muscles (Rodrigues et al., 2007).

Using knock-out strains or knocking down expression of polyQ proteins with a siRNA loaded diet has provided another method for the study of polyQ distribution and function. The knockdown of ataxin-2 by siRNA results in reduced numbers of eggs and developmental arrest whereas the knock-out of this gene was embryonically lethal (Kiehl et al., 2000). In comparison, the knock-out of ataxin-3 results in viable animals, which show no obvious morphological abnormalities as well as normal lifespan and behaviour (Rodrigues et al., 2007) but a significantly increased resistance to stress (Rodrigues et al., 2011).

Aside from protein distribution $C$. elegans has been used to study synaptic function (Khan et al., 2006) and to perform genome-wide RNAi-based genetic screens to identify modifiers (Poole et al., 2011). Such a RNAi screen identified that the aggregation of pure polyQ repeats was enhanced by factors involved in RNA metabolism and protein synthesis (leading to an increased production of misfolded proteins) as well as factors involved in protein folding, transport and degradation (leading to decreased protein clearance) (Nollen et al., 2004).

Invertebrate models, like C. elegans, are also particularly useful models for first-line screenings of possible therapeutic compounds, especially in late-onset neurodegenerative diseases such as SCA. The useful nature of $C$. elegans in such screenings was demonstrated in 2007 when a first drug screening for Huntington's disease was published. Voisine et al. developed a so called food clearance assay by exploiting that $C$. elegans can easily be cultured in solution. For this assay, wildtype C. elegans were incubated in E. coli liquid culture to determine the optimal drug concentration. The optical density was used to measure the consumption of $E$. coli (food source) to indicate the growth or survival of $C$. elegans. Drugs in the established concentrations were then used to treat worms with a polyQ expanded huntingtin (Htn-Q150) and analyzed using a starvation assay (by measuring the presence or absence of GFP expression in neurons). In this assay, a HDAC inhibitor (Trichostatin, TSA) was able to suppress neurodegeneration and $\mathrm{LiCl}$ decreased polyQinduced neurodegeneration, while $\mathrm{NaCl}$ had no effect (Voisine et al., 2007). 
Although no single model organism is able to recapitulate all features of a human disease, $C$. elegans models have proven to be a very good starting point. Worm models allow answering research relevant questions in vivo in an easy to handle and "low-cost" organism, before generating a more complex and expensive, but also more comparable model to human diseases, like mouse models.

\subsection{Lessons learned from fly models}

A big advantage of disease models involving Drosophila melanogaster is the so called GAL4UAS system (Brand and Perrimon, 1993; Fischer et al., 1988). A specific promoter controls the expression of the transcription factor GAL4 which binds the UAS (upstream activating sequence) in the responder construct containing the gene of interest. The use of different promoter GAL4-lines, thereby, allows controlling the expression strength and/or directing the expression of the disease-causing gene to different organs or cell types. A frequently chosen promoter is the mainly eye specific gmr-GAL4 driver (Freeman, 1996) directing the transgene to the flies eyes. Drosophila eyes are highly organized structures thereby allowing a macroscopic observation of the degeneration of (visual) neurons without the need of even preparing and staining brain sections. The high reproducibility, the simple breeding and the ease of analyzing neurodegeneration macroscopically make Drosophila models the ideal tool for the screening for and analysis of factors influencing neurodegenerative events in SCA. However, not all genes causing SCA are conserved in flies, e.g. there are no natural orthologues for ataxin-3 and ataxin-7 in Drosophila melanogaster. However, the CACNA1A, the affected gene in SCA6, as well as ataxin-1 (Tsuda et al., 2005) and ataxin-2 seem to be conserved albeit with only reduced homology (Rubin et al., 2000) as the CAG repeat is missing in these genes. This lack of endogenous genes excludes any knock-in or knock-out approaches and at first sight questions the chance of successful generation of transgenic models for these diseases as relevant binding partners for the affected proteins may also not be conserved. Interestingly, the sole overexpression of the Drosophila orthologue of ataxin-1 (dAtx-1) induced a similar phenotype than the overexpression of human ataxin-1 (hATXN1) although $d A t x-1$ misses more than $60 \%$ of $h A T X N 1$ amino acids including the polyQ repeat (Tsuda et al., 2005). Not even a polyQ expansion is required as a high level of hATXN1 with normal repeat length (30Q) caused neuronal degeneration (Fernandez-Funez et al., 2000). This data indicates that both Drosophila and human ataxin-1 are "intrinsically toxic at high levels" (Lu and Vogel, 2009). Likewise, the overexpression of dAtx2, the Drosophila orthologue of human ataxin-2, caused developmental defects and degeneration of tissues (Satterfield et al., 2002). As well the loss of dAtx2 had comparable effects, stressing the importance of maintaining normal ataxin-2 activity (Satterfield et al., 2002).

Analyses using Drosophila connected pathogenic mechanisms in SCA1, SCA2, and SCA3 and identified ataxin-2 as a potential key player both in SCA1 and SCA3 (Al-Ramahi et al., 2007; Lessing and Bonini, 2008): In both cases, the overexpression of dAtx2 enhanced the neurodegeneration caused by ataxin-1 and ataxin-3, respectively, and downregulation of $d A t \times 2$ had the opposite effect. Comparable observations were made even for a non-polyQ disease, amyotrophic lateral sclerosis (ALS) (Bonini and Gitler, 2011). This influence of $d A t x 2$ seems to be linked to the conserved PAM2 motif (PABP-interacting motif 2) within ataxin-2 which mediates the interaction of ataxin-2 with the Poly(A)-binding protein (PABP) (Lessing and Bonini, 2008) implicating ataxin-2 in the regulation of translation of specific mRNAs (Satterfield and Pallanck, 2006). The general importance of protein domains apart from the 
polyQ repeat were first addressed using pure polyQ repeats which proved to be toxic in Drosophila in expanded, but not in normal lengths (Marsh et al., 2000). However, adding as few as 26 additional amino acids (such as addition of a myc and a FLAG tag) and even more, adding the surrounding amino acids of a full protein is able to even neutralize the toxic effect of expanded polyQ repeats (Marsh et al., 2000).

Drosophila models were also used to assess the relevance of the intracellular localization of the affected protein: Ataxin-2 is normally a cytoplasmic protein and the occurrence of intranuclear aggregates in SCA2 patients is still controversial as both the presence and absence of nuclear aggregates have been described (Huynh et al., 2000; Koyano et al., 2000). However, the intracellular localization of dAtx2 strongly influences the phenotype in flies. While nuclear dAtx2 induces strong neurodegeneration, the phenotype of flies with cytoplasmic dAtx2 is much milder (Al-Ramahi et al., 2007).

As SCA are neurodegenerative disorders, with ubiquitous expression of the disease causing gene in humans, glial cells are usually not the main focus of interest. However the choice of different driver lines allows for the analysis of glial vs. neuronal expression of the diseasecausing genes in Drosophila. Data suggest that the effect of glial expression of the transgene is more pronounced than of neuronal expression (Kretzschmar et al., 2005).

Another strong advantage of Drosophila as a model organism is the suitability for large-scale screens for modifying factors. Such screens for ataxin-1, ataxin-3 or even pure polyQ repeats identified somehow expected proteins involved in protein folding (like chaperones) and protein degradation (components of the ubiquitin-proteasome system and autophagy) (Bilen and Bonini, 2007; Fernandez-Funez et al., 2000; Kazemi-Esfarjani and Benzer, 2000; Latouche et al., 2007). In addition, these screens gave insight into further mechanisms relevant for polyQ disease pathogenesis like cellular detoxification, protein transport, transcriptional regulation and RNA and miRNA processing (Bilen and Bonini, 2007; Bilen et al., 2006; Fernandez-Funez et al., 2000; Latouche et al., 2007). The identification of muscleblind ( $\mathrm{mbl}$ ) as a modifier of an SCA3 fly model drew attention to the role of CAG repeat RNA in the pathogenesis of SCA3 (Li et al., 2008) and led to the conclusion that not only the expanded polyQ repeat but also the RNA coding for it has an effect on the pathogenesis of polyQ diseases at least in Drosophila. Muscleblind is known to be involved in Myotonic dystrophy caused by aberrant RNA containing massive CUG expansions (Jiang et al., 2004). The expression of an untranslated CAG repeat caused neurodegeneration in Drosophila. This toxicity was mitigated just by the interruption of the pure CAG repeat by replacing it with a CAACAG repeat (Li et al., 2008). These results were in line with previous data for a non-polyQ SCA, SCA8, also caused by noncoding RNA. Both a normal and an expanded CAG repeat led to neurodegeneration in a fly model of SCA8 (Mutsuddi et al., 2004). Interestingly, a screen for modifiers of this phenotype caused by non-coding RNA (containing expanded CAG repeats) pointed to several pathways which were also identified as modifiers of a phenotype caused by (translated RNA coding for) expanded polyQ repeats (Mutsuddi et al., 2004). Taken together, disease models in Drosophila facilitated both the identification and further analysis of multiple factors and mechanisms involved in the pathogenesis of SCA.

\section{Lessons learned from mammalian models of SCA}

In contrast to disease models in the worm or the fly, mouse models resemble pathogenic processes in humans much closer than their non-mammalian counterparts. For example the 
brain structure of mice is much closer to that of humans than those of flies or worms and mechanisms of special importance for late-onset diseases like SCA, e.g. gene expression changes during aging (Bishop et al., 2010), are better conserved. In particular, mouse models allow analyzing aspects of the disease which cannot be analyzed in simpler organisms. Although behavioural analyses are possible in C. elegans and Drosophila models, they are rather basic compared to more sophisticated behavioural tests possible with mouse models which even allow for e.g. fear and spatial learning analyses (Huynh et al., 2009).

\subsection{Lessons learned from knock-out mouse models}

In mouse models, it is possible to selectively inactivate a specific gene-of-interest via gene targeting. There is a large amount of insight to be gained from generating such knock-out models and a lot of information has been uncovered about the functional roles of specific genes in mammalian biology (Capecchi, 2005). To learn about the native function of genes affected in SCA knock-out mice were generated for SCA1, 2 and 3. All mice were viable, fertile and had a normal lifespan with no severe ataxic phenotype or neurodegeneration (SCA1: Matilla et al., 1998; SCA2: Kiehl et al., 2006; Lastres-Becker et al., 2008; SCA3: Schmitt et al., 2007; Switonski et al., 2011), providing evidence that loss-of-function is not the primary cause for ataxic symptoms in these disorders. However, these mice served to give indications for normal functions of the respective knock-out genes. For ataxin-1, the gene affected in SCA1, a role in learning and memory was identified (Matilla et al., 1998) and its function as a transcriptional co-regulator was elucidated (Goold et al., 2007). Knocking out the ataxin-2 gene led to adult-onset obesity and reduced fertility (Kiehl et al., 2006; LastresBecker et al., 2008a) as well as hyperactivity and abnormal fear-related behaviour (Huynh et al., 2009). In ataxin-3 knock-out mice increased levels of ubiquitinated proteins were detected reflecting its function as a deubiquitinating enzyme (Schmitt et al., 2007). However, in a second SCA3 knock-out model changes in the ubiquitination level were not observed. The authors suggested compensational effects as the cause for this opposing result (Switonski et al., 2011). Other analyses on SCA3 knock-out mice were able to show a protective function of ataxin-3 in the heat shock response pathway (Reina et al., 2010).

In contrast to only mild effects observed with the deletion of genes responsible for polyQ products, the knock-out of genes affected in non-polyQ SCA resulted in severe ataxic phenotypes. The deletion of the Klhl1 gene which is mutated in SCA8 led to the loss of motor coordination due to degeneration of Purkinje cell function (He et al., 2006). The analysis of mice showing signs of a severe autosomal recessive movement disorder revealed a deletion in the inositol 1,4,5-triphosphate receptor (ITPR1 gene) as the cause of the observed symptoms. Knowing that the gene correlated to SCA15 in humans maps to the ITPR1 genomical region, it was possible to identify a deletion in this gene as the cause of this autosomal dominant disorder (van de Leemput et al., 2007).

Taken together, the analyses of SCA knock-out mice demonstrated a toxic gain-of-function as the cause for SCA due to polyQ expansions, whereas for non-polyQ SCA loss-of-function seems to be the primary mechanism of pathogenesis.

\subsection{Lessons learned from classical transgenic mouse models for SCA}

Transgenic mouse models gave insight into various pathogenic mechanisms in SCA. Here, we review three examples: Lessons learned about the cell-type specificity of neuro- 
degeneration, the aggregation and localization of the affected protein as well as transcriptional dysregulation caused by expanded polyQ proteins.

\subsubsection{Lessons learned about the cell-type specificity of neurodegeneration}

A classical transgenic mouse model is generated by using a specific promoter typically controlling the expression of a cDNA construct of the respective gene-of-interest. The effect of expressing different transgenes in a specific subgroup of neurons can be nicely compared among several proteins affected in SCA as the Purkinje-cell-specific promoter (Pcp2/L7 promoter) (Vandaele et al., 1991) was used for the generation of transgenic mice for SCA1 (Burright et al., 1995), SCA2 (Huynh et al., 2000), SCA3 (Ikeda et al., 1996), SCA7 (Yvert et al., 2000) and SCA17 (Chang et al., 2011), respectively. In the SCA1, SCA2 and SCA17 mouse models the expanded full-length transgene causes a strong degeneration of Purkinje cells (Burright et al., 1995; Chang et al., 2011; Huynh et al., 2000). By contrast, in the SCA7 mouse model, the sole expression of full-length ataxin-7 with $90 \mathrm{Q}$ induced a behavioural phenotype, but only mild degeneration of Purkinje cells in quite old mice (Yvert et al., 2000). Ironically, the expression of full-length ataxin-7 (92 Q) in most neurons except for Purkinje cells (Garden et al., 2002; La Spada et al., 2001) or even just in Bergmann glia cells (Custer et al., 2006), led to a strong degeneration of Purkinje cells (Custer et al., 2006). Likewise, when a full-length ataxin-3 protein with $79 \mathrm{Q}$ was expressed using the same promoter, no phenotype was induced. Only a fragment containing not more than a few amino acids surrounding the expanded polyQ repeat was able to induce a phenotype (Ikeda et al., 1996). These data demonstrate that Purkinje cells in transgenic mice seem to be more vulnerable by a repeat expansion within ataxin-1, ataxin-2 and ataxin-17, than by an expansion within ataxin-3 and ataxin-7, thereby -at first sight- nicely replicating the situation in humans where Purkinje cells are strongly affected in SCA1 (Cummings et al., 1999a), SCA2 (Lastres-Becker et al., 2008b) and SCA17 (Rolfs et al., 2003), but the loss of Purkinje cells can be observed but is not so prominent in SCA3 patients (Rüb et al., 2002a; Rüb et al., 2002b). In SCA7, however, Purkinje cells are typically affected (Holmberg et al., 1998), thereby possibly indicating that the pathogenic processes leading to Purkinje cell death in SCA7 differ from those in SCA1, SCA2 and SCA17.

\subsubsection{Lessons learned about the aggregation of polyQ proteins and their localization}

A common feature of polyQ as well as other neurodegenerative diseases is the accumulation of insoluble proteins in neurons, a feature recapitulated by most model systems of these disorders. Despite this fact the role of these so called neuronal nuclear inclusions (NIIs) in the pathological processes of polyQ diseases is still controversially discussed but it is known that these structures are associated with pathogenesis. Analysis of a C. elegans model of SCA3 directly linked the formation of aggregates to neuronal dysfunction (Teixeira-Castro et al., 2011), whereas several opposing results in mouse models exist. Observations in transgenic mouse models for SCA1, SCA2, SCA3 and SCA6 (Boy et al., 2010; Cummings et al., 1999b; Huynh et al., 2000; Klement et al., 1998; Silva-Fernandes et al., 2010; Watase et al., 2008) reveal that the development of a pathological phenotype is independent of the formation of inclusions excluding large aggregates as a primary cause for neuronal dysfunction. Even more, evidence exists for a protective role of inclusion bodies (Bowman et al., 2005). Inclusions in human SCA patients and respective mouse models stain positive for 
ubiquitin and other components of the ubiquitin-proteasome-system (UPS) (Bichelmeier et al., 2007; Cummings et al., 1998; Holmberg et al., 1998; Klement et al., 1998; Koyano et al., 1999; Paulson et al., 1997; Schmidt et al., 2002; Watase et al., 2002; Yvert et al., 2000) pointing to an involvement of this protein degradation system in the clearance of proteins with expanded CAG repeats. In C. elegans it was observed that expanded polyQ tracts impair the functions of UPS (Khan et al., 2006). In brains of SCA3 patients a marked misdistribution of proteasomal subunits was detected leaving only a subpopulation of neurons with the possibility to form functional proteasome complexes (Schmidt et al., 2002). Comparable results were obtained for SCA1 patients and transgenic mice (Cummings et al., 1998) and further studies revealed that an impairment or altered function of the ubiquitin and the proteasomal degradation system could contribute to the SCA1 pathogenesis (Cummings et al., 1999b; Hong et al., 2002). Data gained using a knock-in model, though, excluded an impairment of the ubiquitin-proteasome-system as a major neuropathological cause of SCA7 (Bowman et al., 2005).

The mechanism which leads to the formation of aggregates is not well understood. It has been proposed that proteolytic cleavage of polyQ-containing proteins is required for aggregate formation, because polyQ-containing fragments are predominantly found in NIIs. Another indication for the cleavage hypotheses is the detection of protein fragments in brains of mouse models for SCA3 (Goti et al., 2004), SCA7 (Garden et al., 2002) and SCA17 (Friedman et al., 2008) as well as human SCA patients (Garden et al., 2002; Goti et al., 2004). As possible protein cleavage enzymes, caspases or calpains are under controversial discussion. For ataxin-3, calpain (Haacke et al., 2007; Koch et al., 2011) and caspase cleavage was analyzed in vitro (Berke et al., 2004; Pozzi et al., 2008). It was shown that a C-terminal fragment of ataxin-3 containing the polyQ stretch leads to a more progressive phenotype (Ikeda et al., 1996), but also an N-terminal fragment without the CAG repeats can cause SCA3 symptoms (Hübener et al., 2011). In addition, mice expressing a fragment of the TATA-binding protein (affected in SCA17) exhibit a more severe phenotype (Friedman et al., 2008) than those expressing a full-length protein (Friedman et al., 2007). These studies suggest that cleavage of the affected protein is important for the pathogeneses of polyQ SCA. Although neuronal nuclear inclusions (NIIs) are a common feature of polyQ diseases, in some SCA the affected protein is normally localized in the cytoplasm. For this reason, the question arose whether the intracellular localization of the affected protein is of relevance for the pathogenesis of SCA. For an polyQ expansion within an ectopic protein context (Jackson et al., 2003), for ataxin-1 (Klement et al., 1998) and for ataxin-3 (Bichelmeier et al., 2007) it was demonstrated that the nuclear localization of the affected protein is a requirement for the manifestation of symptoms. Mice in which the respective protein was kept in the cytoplasm typically had less and smaller aggregates and milder or even almost no behavioural phenotype. For SCA1, Emamian et al. (2003) even went one step further demonstrating that although the nuclear localization of ataxin-1 is required, it is not sufficient to induce a phenotype. A serine residue close to the endogenous NLS within ataxin-1 (S776) was required additionally for the induction of a phenotype (Emamian et al., 2003).

\subsubsection{Lessons learned about transcription dysregulation}

Transcriptional dysregulation is a common feature of most polyQ diseases, but the underlying mechanisms which cause the differential regulation remain unknown. Many 
proteins affected in polyQ diseases are functioning as transcription factors/cofactors or at least interact with transcription factors: TBP (SCA17) is a general transcription factor, ataxin7 is a part of a transcriptional co-activator complex and both ataxin- 1 and ataxin-3 interact with various transcription factors (Helmlinger et al., 2006).

Especially for SCA1, the molecular basis of transcriptional dysregulation and therefore its influence on the pathogenesis is thoroughly studied. Transcriptional dysregulation mediated by ataxin- 1 has been attributed to the interaction with the polyQ binding protein 1 (PQBP1). This interaction interferes with the cellular RNA polymerase-dependent transcription (Okazawa et al., 2002). Microarray analyses of SCA1 knock-in and knock-out mice revealed differential expression of proteins involved in calcium signaling (CrespoBarreto et al., 2010). In SCA3 and SCA7, components of the NIIs are transcriptionally dysregulated, including subunits of the proteasome and heat shock proteins (Chou et al., 2010; Chou et al., 2008). Several other transcription factors such as CREB (cAMP response element binding protein) and HDAC proteins and therefore histone deacetylation is often differential regulated in polyQ diseases (McCampbell et al., 2000; McCullough and Grant, 2010). For this reason, treatment studies using HDAC inhibitors such as sodium butyrate were performed (Chou et al., 2011; McCampbell et al., 2001). In several studies, transcriptional dysregulation is associated with the degeneration of specific neurons: for SCA17, a downregulation of TrkA (nerve growth factor receptor) is linked to Purkinje cell degeneration (Shah et al., 2009), or for SCA1 an interaction of ataxin-1 and PQBP1 and therefore transcriptional dysregulation leads to selective neuronal loss in the cerebellum (Okazawa et al., 2002).

\subsection{Lessons learned from YAC, BAC and knock-In mouse models}

In the process of generating classical transgenic mice it is only possible to insert cDNA randomly into the animal genome, not allowing for controlling the expression of the pathogenic gene in the native genetic environment at endogenous levels or excluding alternative splicing events. Therefore, different techniques have been developed to overcome these limitations and to generate models which more closely resemble human disease conditions. One strategy was the use of a yeast artificial chromosome (YAC) containing a large fragment of the human MJD1 locus for the generation of a model for SCA3 thus enabling the expression of a full-length ataxin-3 gene with the endogenous regulatory elements needed for cell specificity and endogenous levels of expression (Cemal et al., 2002). Mice with expanded CAG tracts showed mild and slowly progressing cerebellar symptoms with nuclear inclusions and cell loss in specific brain regions closely resembling main features of the SCA3 disease in humans (Cemal et al., 2002). A likewise approach was used to generate a model for SCA8. Moseley et al. (2006) used a bacterial artificial chromosome (BAC) to control the expression of the SCA8 locus encoding a non-expressed transgene. If they would have used just a classical transgenic construct without $116 \mathrm{~kb}$ of flanking sequences they may not have observed that the construct is indeed expressed in both directions encoding both a non-translated RNA containing a CTG expansion as well as a polyQ containing protein expressed from the opposite strand (Moseley et al., 2006).

A different more widely used strategy in the generation of SCA mouse models is to take advantage of homologous recombination techniques leading to knock-in models. This allows for endogenous levels of expression in proper spatio-temporal patterns (Yoo et al., 
2003). The first knock-in model generated for SCA1 targeted an expanded CAG tract of 78 repeats to the endogenous ataxin-1 mouse locus. These mice reflected genetic repeat instability observed in human SCA1 patients, but showed only mild behavioural changes in late life with no clear neuropathological changes (Lorenzetti et al., 2000). From this first attempt the conclusion was drawn that the short lifespan of mice seems to be a limiting factor and that the longer exposure of the mutant protein in humans might be necessary for the development of neuronal dysfunctions. This drawback can be overcome by either overexpression of mutant proteins or by the use of extremely long CAG tracts to produce neurodegeneration (Yoo et al., 2003; Zoghbi and Botas, 2002). Therefore, in the next knock-in model for SCA1, more CAG repeats (154 repeats) were used and this model then indeed resembled main features of the human SCA1 disease (Watase et al., 2002). Analyzing these mice it was also shown that there is no direct relationship between the degree of somatic instability and the selective neuronal toxicity (Watase et al., 2003), but that the selective neuropathology rather arises from alterations in the function of the ataxin-1 protein (Bowman et al., 2007). Furthermore, these mice served to demonstrate that a partial loss-offunction contributes to the SCA1 pathogenesis (Bowman et al., 2007; Crespo-Barreto et al., 2010; Lim et al., 2008). SCA6 knock-in mice with up to 84 (hyperexpanded) CAG repeats in the CACNA1A gene (encoding for a calcium channel subunit) gave evidence against the assumption that the SCA6 pathogenesis is caused by alterations of channel properties and rather indicated that it is due to the accumulation of mutant calcium channels (Saegusa et al., 2007; Watase et al., 2008). In infantile cases of SCA7 expansions of 200-460 CAG repeats were documented (Benton et al., 1998; van de Warrenburg et al., 2001) and knock-in mice with 266 CAG repeats indeed reproduced hallmark features of the infantile disease (Yoo et al., 2003). Using this knock-in model it was shown that polyQ nuclear inclusions seem to have a protective role against neuronal dysfunction, that an impairment of the ubiquitinproteasome-system can be excluded as a major neuropathological cause (Bowman et al., 2005) and that SUMOylation influences the aggregation process of ataxin-7 (Janer et al., 2010). A most recent publication reported on the attempt to generate the first knock-in mouse model of SCA3, but due to unexpected splicing events ended up creating another SCA3 knock-out model (Switonski et al., 2011) showing some of the difficulties which may occur generating animal models.

\subsection{Lessons learned from an alternative strategy to generate mouse models}

An alternative approach for the generation of animal models is the use of viral injections. By using lentiviral vectors it was possible to overexpress wildtype or polyQ expanded ataxin-3 in brain regions of adult wildtype rats. An expression of polyQ-expanded ataxin-3 in the substantia nigra, an area affected in SCA3, led to the formation of ubiquitinated ataxin-3 positive aggregates, loss of dopaminergic markers and an apomorphine-induced turning behaviour. If polyQ expanded ataxin-3 is overexpressed in the striatum or cortex, regions previously not linked to SCA3 pathogenesis, by the lentiviral-based system it results in accumulation of misfolded ataxin-3 and loss of neuronal markers especially in the striatum (Alves et al., 2008b). Using the lentiviral vector system it is also possible to co-express ataxin-3 with knock-down vectors or other proteins and to analyze direct effects in specific brain regions. For example a co-expression of expanded ataxin-3 with beclin, an autophagic protein, led to stimulation of autophagic flux, clearance of mutant ataxin-3 and neuroprotective effects (Nascimento-Ferreira et al., 2011). 


\subsection{Treatment approaches using mouse models}

At the moment, curative treatment for SCA is not possible. Only treatments directed towards alleviating symptoms are available (Duenas et al., 2006). Therefore, one or the most important goal in the research of SCA is the development of a cure.

The basic question of whether any treatment -if available- would be able to even reverse symptoms already manifested was addressed using conditional mouse models. With these models which allow to turn off the pathogenic trangene expression using the Tet-off system it was possible to demonstrate that already developed symptoms of SCA1 and SCA3 indeed can be reversed (Boy et al., 2009; $\mathrm{Zu}$ et al., 2004). Inhibiting or reducing the production of pathogenic proteins could therefore be a powerful tool in the therapy of dominant neurodegenerative diseases. Using the RNA interference (RNAi) technology (Mello and Conte, 2004) to inhibit the expression of mutant ataxin-1 in a mouse model of SCA1 led to improved motor coordination, restored cerebellar morphology as well as resolved ataxin-1 inclusions demonstrating the in vivo potential of this strategy (Xia et al., 2004). RNAi knockdown was also successfully used for a selective allele-specific silencing of mutant ataxin-3 showing to mitigate neuropathological abnormalities in a lentiviral-mediated model of SCA3 (Alves et al., 2008a; Alves et al., 2010) and may be a possible treatment approach. As protein misfolding and impaired protein degradation is implicated in the pathogenesis of polyQ SCA and other related diseases that present with intracellular inclusion bodies, supporting the correction of these alterations might be a therapeutic strategy. In this manner it was possible to show that crossbreeding of SCA1 transgenic mice with mice overexpressing a molecular chaperone leads to the mitigation of the SCA1 phenotype (Cummings et al., 2001).

In addition to genetic approaches, some of the published mouse models have already been used to test the effect of different compounds on the movement phenotype, neuronal loss and aggregate formation: Lithium carbonate enhanced the motor performances and improved spatial learning, but had neither an effect on the distribution and formation of aggregates nor did it improve the lifespan of the SCA1 knock-in mice (Watase et al., 2007). A treatment approach using lithium chloride in a C. elegans model for Huntington's disease, however, was beneficial (Voisine et al., 2007). A dietary supplementation with creatine improved survival and motor performance and delays neuronal atrophy in the R6/2 transgenic mouse model of Huntington's disease. In a SCA2 transgenic mouse model, however, creatine extended the Purkinje cell survival, but was not able to improve or delay ataxic symptoms (Kaemmerer et al., 2001). Two promising studies were performed using transgenic models for SCA3: The HDAC inhibitor sodium butyrate (SB) delayed the onset of ataxic symptoms and improved the survival rate by reversing polyQ induced histone hypoacetylation and transcriptional repression (Chou et al., 2011). In addition, a rapamycin ester (also called temsirolimus or CCI-779) which inhibits the mammalian target of rapamycin and upregulates the protein degradation by autophagy, reduced the number of aggregates and improved the motor performance (Menzies et al., 2010). In a study using a SCA2 mouse model, the $\mathrm{Ca}^{2+}$ stabilizer dantrolene was able both to alleviate motor symptoms and to reduce the loss of Purkinje cells in this model (Liu et al., 2009). Another group used a specific mouse model, the so called rolling mouse Nagoya, which has been suggested as an animal model for some human neurological diseases such as autosomal dominant cerebellar ataxia (SCA6). This model was treated with talrelin, a synthetic 
analogue of the thyrotropin-releasing hormone (TRH) which alters the metabolism of acetylcholine and dopamine and therefore activates the dopaminergic system. Talrelin significantly elevated the cerebellar dopamine and serotonin levels of mice and improved the locomotion phenotype (Nakamura et al., 2005).

Other therapeutical attempts are based on the functional restoration of affected cell populations. Expanded ataxin-1 causes the degeneration of Purkinje cells thereby also negatively effects the synthesis of the insulin-like growth factor-I (IGF-I) a factor promoting Purkinje cell development (Fukudome et al., 2003). Administering this factor to SCA1 transgenic mice (SCA1[82Q]) intranasally led to significant improvement of motor coordinative abilities as well as to partial restoration of Purkinje cell survival (Vig et al., 2006). Using the same SCA1 transgenic model, improved motor skills and a higher Purkinje cell survival rate was reached after grafting neural precursor cells into the cerebellar white matter (Chintawar et al., 2009). Although there is a long way from successful treatment approaches in animal models to clinical application, the recent results give hope that treatment of SCA will be possible in the future.

\section{Commons and differences between SCA models in worms, flies and mice}

It is self-evident that the data acquired in different model organisms especially those obtained in non-vertebrate compared with those from vertebrate models cannot be identical. However, if results obtained in a specific model are to be translated to the situation in humans one would expect that basic mechanisms in the pathogenesis of SCA are conserved among species. Previous studies revealed that many pathogenic mechanisms are indeed comparable among species, however, also indicated that there are some differences between model organisms (Table 2). Orthologues of ataxin-2 can be found all the way down to simple organisms and even in yeast (Table 1). However, the knock-out of ataxin-2 gave rise to contradictory results among model organisms: The knock-out of the endogenous SCA2 gene in the worm and the fly is embryonic lethal. In contrast to that, SCA2 knock-out mice are viable and showed no developmental defects. Further analyses of SCA2 knock-out worms demonstrated that ataxin- 2 is functioning during development, since the knockdown by RNAi results in developmental arrest.

These results indicate that the function of homologous proteins as well as the interaction of different proteins in special pathways is not conserved in the species analyzed (Kiehl et al., 2006; Kiehl et al., 2000; Lastres-Becker et al., 2008a; Satterfield et al., 2002). Since in C. elegans the polyQ repeats in all orthologous genes are not conserved, one could assume that much shorter repeat expansions than e.g. in the mouse may already give rise to a phenotype. However, the exact opposite seems to be true: Within the full-length context of a protein, much higher polyQ repeat numbers are required to be toxic (Khan et al., 2006; TeixeiraCastro et al., 2011). Proteins with polyQ repeats are frequent in Drosophila (Alba et al., 2007), but these repeats are generally encoded by interrupted rather than pure CAG repeats and, therefore, more resistant to expansion (Alba et al., 2001). This could lead to the assumption that pure CAG repeats may behave unstable in Drosophila as observed in human SCA patients and mouse models (Boy et al., 2010; Kaytor et al., 1997; Lorenzetti et al., 2000). However, CAG repeats seem to be perfectly stable in Drosophila even within a challenging genomic context (Jackson et al., 2005) pointing to a specific protection mechanism against repeat expansion in Drosophila. 


\begin{tabular}{|c|c|c|c|}
\hline & $\begin{array}{l}\text { Caenorhabditis } \\
\text { elegans }\end{array}$ & $\begin{array}{l}\text { Drosophila } \\
\text { melanogaster }\end{array}$ & Mus musculus \\
\hline knock-out & $\begin{array}{l}\text { SCA2: lethal (1) } \\
\text { SCA3: viable (2) }\end{array}$ & SCA2: lethal (3) & SCA1/2/3/8: viable (4-9) \\
\hline $\begin{array}{l}\text { overexpression of pure polyQ causes } \\
\text { phenotype }\end{array}$ & yes $(10 ; 11)$ & yes (12) & yes $(13 ; 14)$ \\
\hline $\begin{array}{l}\text { truncated protein requires less } \\
\text { repeats to induce phenotype }\end{array}$ & yes (15) & yes (16) & yes (13) \\
\hline full-length protein causes phenotype & yes $(\geq 130$ Q) $(15$ & $\begin{array}{c}\text { wt: no or mild } \\
\text { exp: strong } \\
(3 ; 18-22)\end{array}$ & $\begin{array}{c}\text { wt: no } \\
\text { exp: mild to strong } \\
(23-26)\end{array}$ \\
\hline instability of repeats & & no $(27)$ & $\begin{array}{l}\text { SCA1/3: yes (28-30) } \\
\text { SCA2: no (24) }\end{array}$ \\
\hline repeat numbers causing phenotype & $\geq 130 \mathrm{Q}(15 ; 17)$ & $\geq 30 \mathrm{Q}(18)$ & $\geq 30 \mathrm{Q}(18 ; 24 ; 26)$ \\
\hline $\begin{array}{l}\text { increasing repeat length intensifies } \\
\text { phenotype }\end{array}$ & yes $(15 ; 17)$ & yes $(3 ; 18-22)$ & yes (23-26) \\
\hline formation of aggregates & yes $(15 ; 17)$ & yes (31) & $\begin{array}{c}\text { yes }(33 ; 25) \\
\text { no }(24 ; 32) \\
\text { late }(30 ; 34)\end{array}$ \\
\hline neurodegeneration/ neuronal loss & & yes $(18 ; 19 ; 35)$ & $\begin{array}{c}\text { wt: no } \\
\text { exp: mild to strong } \\
(13 ; 23 ; 24 ; 36)\end{array}$ \\
\hline $\begin{array}{l}\text { switching-off led to reversal } \\
\text { of symptom }\end{array}$ & & yes (31) & yes $(30 ; 37)$ \\
\hline transgene leads to reduced lifespan & yes (17) & yes (31) & yes (25) \\
\hline
\end{tabular}

References: (1) Kiehl et al., 2000; (2) Rodrigues et al., 2007; (3) Satterfield et al., 2002; (4) Matilla et al., 1998; (5) Kiehl et al., 2006; (6) Lastres-Becker et al., 2008a; (7) Schmitt et al., 2007 ; (8) Switonski et al., 2011; (9) He et al., 2006; (10) Brignull et al., 2006a ; (11) Morley et al., 2002; (12) Marsh et al., 2000; (13) Ikeda et al., 1996; (14) Ordway et al., 1997; (15) Khan et al., 2006; (16) Lu and Vogel, 2009; (17) TeixeiraCastro et al., 2011); (18) Fernandez-Funez et al., 2000; (19) Al-Ramahi et al., 2007; (20) Warrick et al., 1998; (21) Warrick et al., 2005; (22) Moseley et al., 2006; (23) Burright et al., 1995; (24) Huynh et al., 2000; (25) Bichelmeier et al., 2007; (26) Friedman et al., 2007; (27) Jackson et al., 2005; (28) Kaytor et al., 1997; (29) Lorenzetti et al., 2000; (30) Boy et al., 2009; (31) Latouche et al., 2007; (32) Silva-Fernandes et al., 2010; (33) Cummings et al., 1999b ; (34) Watase et al., 2008; (35) Lessing and Bonini, 2008; (36) Aguiar et al., 2006; (37) Zu et al., 2004

Table 2. Exemplary phenotypical features of human SCA patients compared among model organisms. For clearness, only examples for the respective phenotypic features are listed. The table is not intended to be exhaustive. (wt, normal repeat; exp, expanded repeat).

\section{Conclusion}

Multiple successful attempts generating transgenic animal models for SCA were performed in different species. While each model organism has its own advantages and disadvantages, all animal models contributed to the knowledge about the pathogenesis of SCA. The transparency of C.elegans together with the simplicity to generate transgenic models as well as the option to study neurodegeneration even macroscopically by targeting the gene of interest to the Drosophila eye make smaller organisms like the worm or the fly especially suitable for the screening of compounds or genetic modifiers. Since many pathologic mechanisms in SCA are conserved in these models, there is a high probability that results obtained in worms and flies can be translated to mammals. Although unsuitable for large- 
scale (genetic and compound) screening approaches, mouse models are the ideal tools for verification of screening results in mammals. Viral injections now even allow a comparatively rapid analysis without the need of breeding or even generating transgenic mice. Especially to answer questions which require brain structures closer to humans or for analyses of ataxic movement or even emotional phenotypes, mammalian models are required. Taken together, model organisms are indispensable tools for the analysis of pathogenic mechanisms important for SCA in vivo.

\section{Acknowledgment}

We thank Anna S. Sowa for critical reading of the manuscript.

\section{References}

Aguiar, J.; Fernandez, J.; Aguilar, A.; Mendoza, Y.; Vazquez, M.; Suarez, J.; Berlanga, J.; Cruz, S.; Guillen, G.; Herrera, L.; Velazquez, L.; Santos, N. \& Merino, N. (2006). Ubiquitous expression of human SCA2 gene under the regulation of the SCA2 self promoter cause specific Purkinje cell degeneration in transgenic mice. Neurosci Lett, Vol. 392, No. 3, pp. 202-6, ISSN 0304-3940

Al-Ramahi, I.; Perez, A. M.; Lim, J.; Zhang, M.; Sorensen, R.; de Haro, M.; Branco, J.; Pulst, S. M.; Zoghbi, H. Y. \& Botas, J. (2007). dAtaxin-2 mediates expanded Ataxin-1induced neurodegeneration in a Drosophila model of SCA1. PLoS Genet, Vol. 3, No. 12, pp. e234, ISSN 1553-7404

Alba, M. M.; Santibanez-Koref, M. F. \& Hancock, J. M. (2001). The comparative genomics of polyglutamine repeats: extreme differences in the codon organization of repeatencoding regions between mammals and Drosophila. J Mol Evol, Vol. 52, No. 3, pp. 249-59, ISSN 0022-2844

Alba, M. M.; Tompa, P. \& Veitia, R. A. (2007). Amino acid repeats and the structure and evolution of proteins. Genome Dyn, Vol. 3, No. pp. 119-30, ISSN 1660-9263

Alves, S.; Nascimento-Ferreira, I.; Auregan, G.; Hassig, R.; Dufour, N.; Brouillet, E.; Pedroso de Lima, M. C.; Hantraye, P.; Pereira de Almeida, L. \& Deglon, N. (2008a). Allelespecific RNA silencing of mutant ataxin-3 mediates neuroprotection in a rat model of Machado-Joseph disease. PLoS One, Vol. 3, No. 10, pp. e3341, ISSN 1932-6203

Alves, S.; Nascimento-Ferreira, I.; Dufour, N.; Hassig, R.; Auregan, G.; Nobrega, C.; Brouillet, E.; Hantraye, P.; Pedroso de Lima, M. C.; Deglon, N. \& de Almeida, L. P. (2010). Silencing ataxin-3 mitigates degeneration in a rat model of Machado-Joseph disease: no role for wild-type ataxin-3? Hum Mol Genet, Vol. 19, No. 12, pp. 2380-94, ISSN 1460-2083

Alves, S.; Regulier, E.; Nascimento-Ferreira, I.; Hassig, R.; Dufour, N.; Koeppen, A.; Carvalho, A. L.; Simoes, S.; de Lima, M. C.; Brouillet, E.; Gould, V. C.; Deglon, N. \& de Almeida, L. P. (2008b). Striatal and nigral pathology in a lentiviral rat model of Machado-Joseph disease. Hum Mol Genet, Vol. 17, No. 14, pp. 2071-83, ISSN 14602083

Benton, C. S.; de Silva, R.; Rutledge, S. L.; Bohlega, S.; Ashizawa, T. \& Zoghbi, H. Y. (1998). Molecular and clinical studies in SCA-7 define a broad clinical spectrum and the infantile phenotype. Neurology, Vol. 51, No. 4, pp. 1081-6, ISSN 0028-3878 
Berke, S. J.; Schmied, F. A.; Brunt, E. R.; Ellerby, L. M. \& Paulson, H. L. (2004). Caspasemediated proteolysis of the polyglutamine disease protein ataxin-3. J Neurochem, Vol. 89, No. 4, pp. 908-18, ISSN 0022-3042

Bichelmeier, U.; Schmidt, T.; Hubener, J.; Boy, J.; Ruttiger, L.; Habig, K.; Poths, S.; Bonin, M.; Knipper, M.; Schmidt, W. J.; Wilbertz, J.; Wolburg, H.; Laccone, F. \& Riess, O. (2007). Nuclear localization of ataxin-3 is required for the manifestation of symptoms in SCA3: in vivo evidence. J Neurosci, Vol. 27, No. 28, pp. 7418-28, ISSN 1529-2401

Bilen, J. \& Bonini, N. M. (2007). Genome-wide screen for modifiers of ataxin-3 neurodegeneration in Drosophila. PLoS Genet, Vol. 3, No. 10, pp. 1950-64, ISSN 1553-7404

Bilen, J.; Liu, N.; Burnett, B. G.; Pittman, R. N. \& Bonini, N. M. (2006). MicroRNA pathways modulate polyglutamine-induced neurodegeneration. Mol Cell, Vol. 24, No. 1, pp. 157-63, ISSN 1097-2765

Bishop, N. A.; Lu, T. \& Yankner, B. A. (2010). Neural mechanisms of ageing and cognitive decline. Nature, Vol. 464, No. 7288, pp. 529-35, ISSN 1476-4687

Bonini, N. M. \& Gitler, A. D. (2011). Model Organisms Reveal Insight into Human Neurodegenerative Disease: Ataxin-2 Intermediate-Length Polyglutamine Expansions Are a Risk Factor for ALS. J Mol Neurosci, Vol., No., ISSN 1559-1166

Bowman, A. B.; Lam, Y. C.; Jafar-Nejad, P.; Chen, H. K.; Richman, R.; Samaco, R. C.; Fryer, J. D.; Kahle, J. J.; Orr, H. T. \& Zoghbi, H. Y. (2007). Duplication of Atxn1l suppresses SCA1 neuropathology by decreasing incorporation of polyglutamine-expanded ataxin-1 into native complexes. Nat Genet, Vol. 39, No. 3, pp. 373-9, ISSN 1061-4036

Bowman, A. B.; Yoo, S. Y.; Dantuma, N. P. \& Zoghbi, H. Y. (2005). Neuronal dysfunction in a polyglutamine disease model occurs in the absence of ubiquitin-proteasome system impairment and inversely correlates with the degree of nuclear inclusion formation. Hum Mol Genet, Vol. 14, No. 5, pp. 679-91, ISSN 0964-6906

Boy, J.; Schmidt, T.; Schumann, U.; Grasshoff, U.; Unser, S.; Holzmann, C.; Schmitt, I.; Karl, T.; Laccone, F.; Wolburg, H.; Ibrahim, S. \& Riess, O. (2010). A transgenic mouse model of spinocerebellar ataxia type 3 resembling late disease onset and genderspecific instability of CAG repeats. Neurobiol Dis, Vol. 37, No. 2, pp. 284-93, ISSN 1095-953X

Boy, J.; Schmidt, T.; Wolburg, H.; Mack, A.; Nuber, S.; Bottcher, M.; Schmitt, I.; Holzmann, C.; Zimmermann, F.; Servadio, A. \& Riess, O. (2009). Reversibility of symptoms in a conditional mouse model of spinocerebellar ataxia type 3. Hum Mol Genet, Vol. 18, No. 22, pp. 4282-95, ISSN 1460-2083

Brand, A. H. \& Perrimon, N. (1993). Targeted gene expression as a means of altering cell fates and generating dominant phenotypes. Development, Vol. 118, No. 2, pp. 40115, ISSN 0950-1991

Brignull, H. R.; Moore, F. E.; Tang, S. J. \& Morimoto, R. I. (2006a). Polyglutamine proteins at the pathogenic threshold display neuron-specific aggregation in a pan-neuronal Caenorhabditis elegans model. J Neurosci, Vol. 26, No. 29, pp. 7597-606, ISSN 15292401

Brignull, H. R.; Morley, J. F.; Garcia, S. M. \& Morimoto, R. I. (2006b). Modeling polyglutamine pathogenesis in C. elegans. Methods Enzymol, Vol. 412, No. pp. 25682, ISSN 0076-6879 
Burright, E. N.; Clark, H. B.; Servadio, A.; Matilla, T.; Feddersen, R. M.; Yunis, W. S.; Duvick, L. A.; Zoghbi, H. Y. \& Orr, H. T. (1995). SCA1 transgenic mice: a model for neurodegeneration caused by an expanded CAG trinucleotide repeat. Cell, Vol. 82, No. 6, pp. 937-48, ISSN 0092-8674

Capecchi, M. R. (2005). Gene targeting in mice: functional analysis of the mammalian genome for the twenty-first century. Nat Rev Genet, Vol. 6, No. 6, pp. 507-12, ISSN 1471-0056

Cemal, C. K.; Carroll, C. J.; Lawrence, L.; Lowrie, M. B.; Ruddle, P.; Al-Mahdawi, S.; King, R. H.; Pook, M. A.; Huxley, C. \& Chamberlain, S. (2002). YAC transgenic mice carrying pathological alleles of the MJD1 locus exhibit a mild and slowly progressive cerebellar deficit. Hum Mol Genet, Vol. 11, No. 9, pp. 1075-94, ISSN 0964-6906

Chang, Y. C.; Lin, C. Y.; Hsu, C. M.; Lin, H. C.; Chen, Y. H.; Lee-Chen, G. J.; Su, M. T.; Ro, L. S.; Chen, C. M. \& Hsieh-Li, H. M. (2011). Neuroprotective effects of granulocytecolony stimulating factor in a novel transgenic mouse model of SCA17. J Neurochem, Vol. 118, No. 2, pp. 288-303, ISSN 1471-4159

Chintawar, S.; Hourez, R.; Ravella, A.; Gall, D.; Orduz, D.; Rai, M.; Bishop, D. P.; Geuna, S.; Schiffmann, S. N. \& Pandolfo, M. (2009). Grafting neural precursor cells promotes functional recovery in an SCA1 mouse model. J Neurosci, Vol. 29, No. 42, pp. 1312635, ISSN 1529-2401

Chou, A. H.; Chen, C. Y.; Chen, S. Y.; Chen, W. J.; Chen, Y. L.; Weng, Y. S. \& Wang, H. L. (2010). Polyglutamine-expanded ataxin-7 causes cerebellar dysfunction by inducing transcriptional dysregulation. Neurochem Int, Vol. 56, No. 2, pp. 329-39, ISSN 18729754

Chou, A. H.; Chen, S. Y.; Yeh, T. H.; Weng, Y. H. \& Wang, H. L. (2011). HDAC inhibitor sodium butyrate reverses transcriptional downregulation and ameliorates ataxic symptoms in a transgenic mouse model of SCA3. Neurobiol Dis, Vol. 41, No. 2, pp. 481-8, ISSN 1095-953X

Chou, A. H.; Yeh, T. H.; Ouyang, P.; Chen, Y. L.; Chen, S. Y. \& Wang, H. L. (2008). Polyglutamine-expanded ataxin-3 causes cerebellar dysfunction of SCA3 transgenic mice by inducing transcriptional dysregulation. Neurobiol Dis, Vol. 31, No. 1, pp. 89101, ISSN 1095-953X

Ciosk, R.; DePalma, M. \& Priess, J. R. (2004). ATX-2, the C. elegans ortholog of ataxin 2, functions in translational regulation in the germline. Development, Vol. 131, No. 19, pp. 4831-41, ISSN 0950-1991

Crespo-Barreto, J.; Fryer, J. D.; Shaw, C. A.; Orr, H. T. \& Zoghbi, H. Y. (2010). Partial loss of ataxin-1 function contributes to transcriptional dysregulation in spinocerebellar ataxia type 1 pathogenesis. PLoS Genet, Vol. 6, No. 7, pp. e1001021, ISSN 1553-7404

Cummings, C. J.; Mancini, M. A.; Antalffy, B.; DeFranco, D. B.; Orr, H. T. \& Zoghbi, H. Y. (1998). Chaperone suppression of aggregation and altered subcellular proteasome localization imply protein misfolding in SCA1. Nat Genet, Vol. 19, No. 2, pp. 148-54, ISSN 1061-4036

Cummings, C. J.; Orr, H. T. \& Zoghbi, H. Y. (1999a). Progress in pathogenesis studies of spinocerebellar ataxia type 1. Philos Trans $R$ Soc Lond B Biol Sci, Vol. 354, No. 1386, pp. 1079-81, ISSN 0962-8436 
Cummings, C. J.; Reinstein, E.; Sun, Y.; Antalffy, B.; Jiang, Y.; Ciechanover, A.; Orr, H. T.; Beaudet, A. L. \& Zoghbi, H. Y. (1999b). Mutation of the E6-AP ubiquitin ligase reduces nuclear inclusion frequency while accelerating polyglutamine-induced pathology in SCA1 mice. Neuron, Vol. 24, No. 4, pp. 879-92, ISSN 0896-6273

Cummings, C. J.; Sun, Y.; Opal, P.; Antalffy, B.; Mestril, R.; Orr, H. T.; Dillmann, W. H. \& Zoghbi, H. Y. (2001). Over-expression of inducible HSP70 chaperone suppresses neuropathology and improves motor function in SCA1 mice. Hum Mol Genet, Vol. 10, No. 14, pp. 1511-8, ISSN 0964-6906

Custer, S. K.; Garden, G. A.; Gill, N.; Rueb, U.; Libby, R. T.; Schultz, C.; Guyenet, S. J.; Deller, T.; Westrum, L. E.; Sopher, B. L. \& La Spada, A. R. (2006). Bergmann glia expression of polyglutamine-expanded ataxin-7 produces neurodegeneration by impairing glutamate transport. Nat Neurosci, Vol. 9, No. 10, pp. 1302-11, ISSN 1097-6256

Driscoll, M. \& Gerstbrein, B. (2003). Dying for a cause: invertebrate genetics takes on human neurodegeneration. Nat Rev Genet, Vol. 4, No. 3, pp. 181-94, ISSN 1471-0056

Duenas, A. M.; Goold, R. \& Giunti, P. (2006). Molecular pathogenesis of spinocerebellar ataxias. Brain, Vol. 129, No. Pt 6, pp. 1357-70, ISSN 1460-2156

Emamian, E. S.; Kaytor, M. D.; Duvick, L. A.; Zu, T.; Tousey, S. K.; Zoghbi, H. Y.; Clark, H. B. \& Orr, H. T. (2003). Serine 776 of ataxin-1 is critical for polyglutamine-induced disease in SCA1 transgenic mice. Neuron, Vol. 38, No. 3, pp. 375-87, ISSN 0896-6273

Fernandez-Funez, P.; Nino-Rosales, M. L.; de Gouyon, B.; She, W. C.; Luchak, J. M.; Martinez, P.; Turiegano, E.; Benito, J.; Capovilla, M.; Skinner, P. J.; McCall, A.; Canal, I.; Orr, H. T.; Zoghbi, H. Y. \& Botas, J. (2000). Identification of genes that modify ataxin-1-induced neurodegeneration. Nature, Vol. 408, No. 6808, pp. 101-6, ISSN 0028-0836

Fischer, J. A.; Giniger, E.; Maniatis, T. \& Ptashne, M. (1988). GAL4 activates transcription in Drosophila. Nature, Vol. 332, No. 6167, pp. 853-6, ISSN 0028-0836

Freeman, M. (1996). Reiterative use of the EGF receptor triggers differentiation of all cell types in the Drosophila eye. Cell, Vol. 87, No. 4, pp. 651-60, ISSN 0092-8674

Friedman, M. J.; Shah, A. G.; Fang, Z. H.; Ward, E. G.; Warren, S. T.; Li, S. \& Li, X. J. (2007). Polyglutamine domain modulates the TBP-TFIIB interaction: implications for its normal function and neurodegeneration. Nat Neurosci, Vol. 10, No. 12, pp. 1519-28, ISSN 1097-6256

Friedman, M. J.; Wang, C. E.; Li, X. J. \& Li, S. (2008). Polyglutamine expansion reduces the association of TATA-binding protein with DNA and induces DNA bindingindependent neurotoxicity. J Biol Chem, Vol. 283, No. 13, pp. 8283-90, ISSN 00219258

Fukudome, Y.; Tabata, T.; Miyoshi, T.; Haruki, S.; Araishi, K.; Sawada, S. \& Kano, M. (2003). Insulin-like growth factor-I as a promoting factor for cerebellar Purkinje cell development. Eur J Neurosci, Vol. 17, No. 10, pp. 2006-16, ISSN 0953-816X

Garden, G. A.; Libby, R. T.; Fu, Y. H.; Kinoshita, Y.; Huang, J.; Possin, D. E.; Smith, A. C.; Martinez, R. A.; Fine, G. C.; Grote, S. K.; Ware, C. B.; Einum, D. D.; Morrison, R. S.; Ptacek, L. J.; Sopher, B. L. \& La Spada, A. R. (2002). Polyglutamine-expanded ataxin-7 promotes non-cell-autonomous purkinje cell degeneration and displays proteolytic cleavage in ataxic transgenic mice. J Neurosci, Vol. 22, No. 12, pp. 4897905, ISSN 1529-2401 
Goold, R.; Hubank, M.; Hunt, A.; Holton, J.; Menon, R. P.; Revesz, T.; Pandolfo, M. \& Matilla-Duenas, A. (2007). Down-regulation of the dopamine receptor D2 in mice lacking ataxin 1. Hum Mol Genet, Vol. 16, No. 17, pp. 2122-34, ISSN 0964-6906

Goti, D.; Katzen, S. M.; Mez, J.; Kurtis, N.; Kiluk, J.; Ben-Haiem, L.; Jenkins, N. A.; Copeland, N. G.; Kakizuka, A.; Sharp, A. H.; Ross, C. A.; Mouton, P. R. \& Colomer, V. (2004). A mutant ataxin-3 putative-cleavage fragment in brains of Machado-Joseph disease patients and transgenic mice is cytotoxic above a critical concentration. J Neurosci, Vol. 24, No. 45, pp. 10266-79, ISSN 1529-2401

Haacke, A.; Hartl, F. U. \& Breuer, P. (2007). Calpain inhibition is sufficient to suppress aggregation of polyglutamine-expanded ataxin-3. J Biol Chem, Vol. 282, No. 26, pp. 18851-6, ISSN 0021-9258

He, Y.; Zu, T.; Benzow, K. A.; Orr, H. T.; Clark, H. B. \& Koob, M. D. (2006). Targeted deletion of a single Sca8 ataxia locus allele in mice causes abnormal gait, progressive loss of motor coordination, and Purkinje cell dendritic deficits. J Neurosci, Vol. 26, No. 39, pp. 9975-82, ISSN 1529-2401

Helmlinger, D.; Tora, L. \& Devys, D. (2006). Transcriptional alterations and chromatin remodeling in polyglutamine diseases. Trends Genet, Vol. 22, No. 10, pp. 562-70, ISSN 0168-9525

Holmberg, M.; Duyckaerts, C.; Durr, A.; Cancel, G.; Gourfinkel-An, I.; Damier, P.; Faucheux, B.; Trottier, Y.; Hirsch, E. C.; Agid, Y. \& Brice, A. (1998). Spinocerebellar ataxia type 7 (SCA7): a neurodegenerative disorder with neuronal intranuclear inclusions. Hum Mol Genet, Vol. 7, No. 5, pp. 913-8, ISSN 0964-6906

Hong, S.; Kim, S. J.; Ka, S.; Choi, I. \& Kang, S. (2002). USP7, a ubiquitin-specific protease, interacts with ataxin-1, the SCA1 gene product. Mol Cell Neurosci, Vol. 20, No. 2, pp. 298-306, ISSN 1044-7431

Hübener, J.; Vauti, F.; Funke, C.; Wolburg, H.; Ye, Y.; Schmidt, T.; Wolburg-Buchholz, K.; Schmitt, I.; Gardyan, A.; Driessen, S.; Arnold, H. H.; Nguyen, H. P. \& Riess, O. (2011). N-terminal ataxin-3 causes neurological symptoms with inclusions, endoplasmic reticulum stress and ribosomal dislocation. Brain, Vol. 134, No. Pt 7, pp. 1925-1942, ISSN 1460-2156

Huynh, D. P.; Figueroa, K.; Hoang, N. \& Pulst, S. M. (2000). Nuclear localization or inclusion body formation of ataxin-2 are not necessary for SCA2 pathogenesis in mouse or human. Nat Genet, Vol. 26, No. 1, pp. 44-50, ISSN 1061-4036

Huynh, D. P.; Maalouf, M.; Silva, A. J.; Schweizer, F. E. \& Pulst, S. M. (2009). Dissociated fear and spatial learning in mice with deficiency of ataxin-2. PLoS One, Vol. 4, No. 7, pp. e6235, ISSN 1932-6203

Ikeda, H.; Yamaguchi, M.; Sugai, S.; Aze, Y.; Narumiya, S. \& Kakizuka, A. (1996). Expanded polyglutamine in the Machado-Joseph disease protein induces cell death in vitro and in vivo. Nat Genet, Vol. 13, No. 2, pp. 196-202, ISSN 1061-4036

Jackson, S. M.; Whitworth, A. J.; Greene, J. C.; Libby, R. T.; Baccam, S. L.; Pallanck, L. J. \& La Spada, A. R. (2005). A SCA7 CAG/CTG repeat expansion is stable in Drosophila melanogaster despite modulation of genomic context and gene dosage. Gene, Vol. 347, No. 1, pp. 35-41, ISSN 0378-1119

Jackson, W. S.; Tallaksen-Greene, S. J.; Albin, R. L. \& Detloff, P. J. (2003). Nucleocytoplasmic transport signals affect the age at onset of abnormalities in knock-in mice 
expressing polyglutamine within an ectopic protein context. Hum Mol Genet, Vol. 12, No. 13, pp. 1621-9, ISSN 0964-6906

Janer, A.; Werner, A.; Takahashi-Fujigasaki, J.; Daret, A.; Fujigasaki, H.; Takada, K.; Duyckaerts, C.; Brice, A.; Dejean, A. \& Sittler, A. (2010). SUMOylation attenuates the aggregation propensity and cellular toxicity of the polyglutamine expanded ataxin-7. Hum Mol Genet, Vol. 19, No. 1, pp. 181-95, ISSN 1460-2083

Jiang, H.; Mankodi, A.; Swanson, M. S.; Moxley, R. T. \& Thornton, C. A. (2004). Myotonic dystrophy type 1 is associated with nuclear foci of mutant RNA, sequestration of muscleblind proteins and deregulated alternative splicing in neurons. Hum Mol Genet, Vol. 13, No. 24, pp. 3079-88, ISSN 0964-6906

Kaemmerer, W. F.; Rodrigues, C. M.; Steer, C. J. \& Low, W. C. (2001). Creatinesupplemented diet extends Purkinje cell survival in spinocerebellar ataxia type 1 transgenic mice but does not prevent the ataxic phenotype. Neuroscience, Vol. 103, No. 3, pp. 713-24, ISSN 0306-4522

Kaytor, M. D.; Burright, E. N.; Duvick, L. A.; Zoghbi, H. Y. \& Orr, H. T. (1997). Increased trinucleotide repeat instability with advanced maternal age. Hum Mol Genet, Vol. 6, No. 12, pp. 2135-9, ISSN 0964-6906

Kazemi-Esfarjani, P. \& Benzer, S. (2000). Genetic suppression of polyglutamine toxicity in Drosophila. Science, Vol. 287, No. 5459, pp. 1837-40, ISSN 0036-8075

Khan, L. A.; Bauer, P. O.; Miyazaki, H.; Lindenberg, K. S.; Landwehrmeyer, B. G. \& Nukina, N. (2006). Expanded polyglutamines impair synaptic transmission and ubiquitinproteasome system in Caenorhabditis elegans. J Neurochem, Vol. 98, No. 2, pp. 57687, ISSN 0022-3042

Khurana, V. \& Lindquist, S. (2010). Modelling neurodegeneration in Saccharomyces cerevisiae: why cook with baker's yeast? Nat Rev Neurosci, Vol. 11, No. 6, pp. 436-49, ISSN 1471-0048

Kiehl, T. R.; Nechiporuk, A.; Figueroa, K. P.; Keating, M. T.; Huynh, D. P. \& Pulst, S. M. (2006). Generation and characterization of Sca2 (ataxin-2) knockout mice. Biochem Biophys Res Commun, Vol. 339, No. 1, pp. 17-24, ISSN 0006-291X

Kiehl, T. R.; Shibata, H. \& Pulst, S. M. (2000). The ortholog of human ataxin-2 is essential for early embryonic patterning in C. elegans. J Mol Neurosci, Vol. 15, No. 3, pp. 231-41, ISSN 0895-8696

Klement, I. A.; Skinner, P. J.; Kaytor, M. D.; Yi, H.; Hersch, S. M.; Clark, H. B.; Zoghbi, H. Y. \& Orr, H. T. (1998). Ataxin-1 nuclear localization and aggregation: role in polyglutamine-induced disease in SCA1 transgenic mice. Cell, Vol. 95, No. 1, pp. 41-53, ISSN 0092-8674

Koch, P.; Breuer, P.; Peitz, M.; Jungverdorben, J.; Kesavan, J.; Poppe, D.; Doerr, J.; Ladewig, J.; Mertens, J.; Tüting, T.; Hoffmann, P.; Klockgether, T.; Evert, B. O.; Wüllner, U.; Brüstle, O. (2011). Excitation-induced ataxin-3 aggregation in neurons from patients with Machado-Joseph disease. Nature, Epub ahead of print, ISSN 1476-4687

Koyano, S.; Uchihara, T.; Fujigasaki, H.; Nakamura, A.; Yagishita, S. \& Iwabuchi, K. (1999). Neuronal intranuclear inclusions in spinocerebellar ataxia type 2: triple-labeling immunofluorescent study. Neurosci Lett, Vol. 273, No. 2, pp. 117-20, ISSN 0304-3940

Koyano, S.; Uchihara, T.; Fujigasaki, H.; Nakamura, A.; Yagishita, S. \& Iwabuchi, K. (2000). Neuronal intranuclear inclusions in spinocerebellar ataxia type 2. Ann Neurol, Vol. 47, No. 4, pp. 550, ISSN 0364-5134 
Kretzschmar, D.; Tschape, J.; Bettencourt Da Cruz, A.; Asan, E.; Poeck, B.; Strauss, R. \& Pflugfelder, G. O. (2005). Glial and neuronal expression of polyglutamine proteins induce behavioral changes and aggregate formation in Drosophila. Glia, Vol. 49, No. 1, pp. 59-72, ISSN 0894-1491

La Spada, A. R.; Fu, Y. H.; Sopher, B. L.; Libby, R. T.; Wang, X.; Li, L. Y.; Einum, D. D.; Huang, J.; Possin, D. E.; Smith, A. C.; Martinez, R. A.; Koszdin, K. L.; Treuting, P. M.; Ware, C. B.; Hurley, J. B.; Ptacek, L. J. \& Chen, S. (2001). Polyglutamineexpanded ataxin-7 antagonizes CRX function and induces cone-rod dystrophy in a mouse model of SCA7. Neuron, Vol. 31, No. 6, pp. 913-27, ISSN 0896-6273

Lastres-Becker, I.; Brodesser, S.; Lutjohann, D.; Azizov, M.; Buchmann, J.; Hintermann, E.; Sandhoff, K.; Schurmann, A.; Nowock, J. \& Auburger, G. (2008a). Insulin receptor and lipid metabolism pathology in ataxin-2 knock-out mice. Hum Mol Genet, Vol. 17, No. 10, pp. 1465-81, ISSN 1460-2083

Lastres-Becker, I.; Rub, U. \& Auburger, G. (2008b). Spinocerebellar ataxia 2 (SCA2). Cerebellum, Vol. 7, No. 2, pp. 115-24, ISSN 1473-4230

Latouche, M.; Lasbleiz, C.; Martin, E.; Monnier, V.; Debeir, T.; Mouatt-Prigent, A.; Muriel, M. P.; Morel, L.; Ruberg, M.; Brice, A.; Stevanin, G. \& Tricoire, H. (2007). A conditional pan-neuronal Drosophila model of spinocerebellar ataxia 7 with a reversible adult phenotype suitable for identifying modifier genes. J Neurosci, Vol. 27, No. 10, pp. 2483-92, ISSN 1529-2401

Lessing, D. \& Bonini, N. M. (2008). Polyglutamine genes interact to modulate the severity and progression of neurodegeneration in Drosophila. PLoS Biol, Vol. 6, No. 2, pp. e29, ISSN 1545-7885

Li, L. B.; Yu, Z.; Teng, X. \& Bonini, N. M. (2008). RNA toxicity is a component of ataxin-3 degeneration in Drosophila. Nature, Vol. 453, No. 7198, pp. 1107-11, ISSN 1476-4687

Lim, J.; Crespo-Barreto, J.; Jafar-Nejad, P.; Bowman, A. B.; Richman, R.; Hill, D. E.; Orr, H. T. \& Zoghbi, H. Y. (2008). Opposing effects of polyglutamine expansion on native protein complexes contribute to SCA1. Nature, Vol. 452, No. 7188, pp. 713-8, ISSN 1476-4687

Liu, J.; Tang, T. S.; Tu, H.; Nelson, O.; Herndon, E.; Huynh, D. P.; Pulst, S. M. \& Bezprozvanny, I. (2009). Deranged calcium signaling and neurodegeneration in spinocerebellar ataxia type 2. J Neurosci, Vol. 29, No. 29, pp. 9148-62, ISSN 15292401

Lorenzetti, D.; Watase, K.; Xu, B.; Matzuk, M. M.; Orr, H. T. \& Zoghbi, H. Y. (2000). Repeat instability and motor incoordination in mice with a targeted expanded CAG repeat in the Sca1 locus. Hum Mol Genet, Vol. 9, No. 5, pp. 779-85, ISSN 0964-6906

Lu, B. \& Vogel, H. (2009). Drosophila models of neurodegenerative diseases. Annu Rev Pathol, Vol. 4, No. pp. 315-42, ISSN 1553-4014

Marsh, J. L.; Walker, H.; Theisen, H.; Zhu, Y. Z.; Fielder, T.; Purcell, J. \& Thompson, L. M. (2000). Expanded polyglutamine peptides alone are intrinsically cytotoxic and cause neurodegeneration in Drosophila. Hum Mol Genet, Vol. 9, No. 1, pp. 13-25, ISSN 0964-6906

Matilla, A.; Roberson, E. D.; Banfi, S.; Morales, J.; Armstrong, D. L.; Burright, E. N.; Orr, H. T.; Sweatt, J. D.; Zoghbi, H. Y. \& Matzuk, M. M. (1998). Mice lacking ataxin-1 display learning deficits and decreased hippocampal paired-pulse facilitation. $J$ Neurosci, Vol. 18, No. 14, pp. 5508-16, ISSN 0270-6474 
McCampbell, A.; Taye, A. A.; Whitty, L.; Penney, E.; Steffan, J. S. \& Fischbeck, K. H. (2001). Histone deacetylase inhibitors reduce polyglutamine toxicity. Proc Natl Acad Sci U S A, Vol. 98, No. 26, pp. 15179-84, ISSN 0027-8424

McCampbell, A.; Taylor, J. P.; Taye, A. A.; Robitschek, J.; Li, M.; Walcott, J.; Merry, D.; Chai, Y.; Paulson, H.; Sobue, G. \& Fischbeck, K. H. (2000). CREB-binding protein sequestration by expanded polyglutamine. Hum Mol Genet, Vol. 9, No. 14, pp. 2197202, ISSN 0964-6906

McCullough, S. D. \& Grant, P. A. (2010). Histone acetylation, acetyltransferases, and ataxia-alteration of histone acetylation and chromatin dynamics is implicated in the pathogenesis of polyglutamine-expansion disorders. Adv Protein Chem Struct Biol, Vol. 79, No. pp. 165-203, ISSN 1876-1631

Mello, C. C. \& Conte, D., Jr. (2004). Revealing the world of RNA interference. Nature, Vol. 431, No. 7006, pp. 338-42, ISSN 1476-4687

Menzies, F. M.; Huebener, J.; Renna, M.; Bonin, M.; Riess, O. \& Rubinsztein, D. C. (2010). Autophagy induction reduces mutant ataxin-3 levels and toxicity in a mouse model of spinocerebellar ataxia type 3. Brain, Vol. 133, No. Pt 1, pp. 93-104, ISSN 1460-2156

Morley, J. F.; Brignull, H. R.; Weyers, J. J. \& Morimoto, R. I. (2002). The threshold for polyglutamine-expansion protein aggregation and cellular toxicity is dynamic and influenced by aging in Caenorhabditis elegans. Proc Natl Acad Sci U S A, Vol. 99, No. 16, pp. 10417-22, ISSN 0027-8424

Moseley, M. L.; Zu, T.; Ikeda, Y.; Gao, W.; Mosemiller, A. K.; Daughters, R. S.; Chen, G.; Weatherspoon, M. R.; Clark, H. B.; Ebner, T. J.; Day, J. W. \& Ranum, L. P. (2006). Bidirectional expression of CUG and CAG expansion transcripts and intranuclear polyglutamine inclusions in spinocerebellar ataxia type 8. Nat Genet, Vol. 38, No. 7, pp. 758-69, ISSN 1061-4036

Mutsuddi, M.; Marshall, C. M.; Benzow, K. A.; Koob, M. D. \& Rebay, I. (2004). The spinocerebellar ataxia 8 noncoding RNA causes neurodegeneration and associates with staufen in Drosophila. Curr Biol, Vol. 14, No. 4, pp. 302-8, ISSN 0960-9822

Nakamura, T.; Honda, M.; Kimura, S.; Tanabe, M.; Oda, S. \& Ono, H. (2005). Taltirelin improves motor ataxia independently of monoamine levels in rolling mouse nagoya, a model of spinocerebellar atrophy. Biol Pharm Bull, Vol. 28, No. 12, pp. 2244-7, ISSN 0918-6158

Nascimento-Ferreira, I.; Santos-Ferreira, T.; Sousa-Ferreira, L.; Auregan, G.; Onofre, I.; Alves, S.; Dufour, N.; Colomer Gould, V. F.; Koeppen, A.; Deglon, N. \& Pereira de Almeida, L. (2011). Overexpression of the autophagic beclin-1 protein clears mutant ataxin-3 and alleviates Machado-Joseph disease. Brain, Vol. 134, No. Pt 5, pp. 140015, ISSN 1460-2156

Nollen, E. A.; Garcia, S. M.; van Haaften, G.; Kim, S.; Chavez, A.; Morimoto, R. I. \& Plasterk, R. H. (2004). Genome-wide RNA interference screen identifies previously undescribed regulators of polyglutamine aggregation. Proc Natl Acad Sci U S A, Vol. 101, No. 17, pp. 6403-8, ISSN 0027-8424

Okazawa, H.; Rich, T.; Chang, A.; Lin, X.; Waragai, M.; Kajikawa, M.; Enokido, Y.; Komuro, A.; Kato, S.; Shibata, M.; Hatanaka, H.; Mouradian, M. M.; Sudol, M. \& Kanazawa, I. (2002). Interaction between mutant ataxin-1 and PQBP-1 affects transcription and cell death. Neuron, Vol. 34, No. 5, pp. 701-13, ISSN 0896-6273 
Ordway, J. M.; Tallaksen-Greene, S.; Gutekunst, C. A.; Bernstein, E. M.; Cearley, J. A.; Wiener, H. W.; Dure, L. S. t.; Lindsey, R.; Hersch, S. M.; Jope, R. S.; Albin, R. L. \& Detloff, P. J. (1997). Ectopically expressed CAG repeats cause intranuclear inclusions and a progressive late onset neurological phenotype in the mouse. Cell, Vol. 91, No. 6, pp. 753-63, ISSN 0092-8674

Paulson, H. L.; Perez, M. K.; Trottier, Y.; Trojanowski, J. Q.; Subramony, S. H.; Das, S. S.; Vig, P.; Mandel, J. L.; Fischbeck, K. H. \& Pittman, R. N. (1997). Intranuclear inclusions of expanded polyglutamine protein in spinocerebellar ataxia type 3. Neuron, Vol. 19, No. 2, pp. 333-44, ISSN 0896-6273

Poole, R. J.; Bashllari, E.; Cochella, L.; Flowers, E. B. \& Hobert, O. (2011). A Genome-Wide RNAi Screen for Factors Involved in Neuronal Specification in Caenorhabditis elegans. PLoS Genet, Vol. 7, No. 6, pp. e1002109, ISSN 1553-7404

Pozzi, C.; Valtorta, M.; Tedeschi, G.; Galbusera, E.; Pastori, V.; Bigi, A.; Nonnis, S.; Grassi, E. \& Fusi, P. (2008). Study of subcellular localization and proteolysis of ataxin-3. Neurobiol Dis, Vol. 30, No. 2, pp. 190-200, ISSN 1095-953X

Reina, C. P.; Zhong, X. \& Pittman, R. N. (2010). Proteotoxic stress increases nuclear localization of ataxin-3. Hum Mol Genet, Vol. 19, No. 2, pp. 235-49, ISSN 1460-2083

Rodrigues, A. J.; Coppola, G.; Santos, C.; Costa Mdo, C.; Ailion, M.; Sequeiros, J.; Geschwind, D. H. \& Maciel, P. (2007). Functional genomics and biochemical characterization of the C. elegans orthologue of the Machado-Joseph disease protein ataxin-3. Faseb J, Vol. 21, No. 4, pp. 1126-36, ISSN 1530-6860

Rodrigues, A. J.; Neves-Carvalho, A.; Teixeira-Castro, A.; Rokka, A.; Corthals, G.; Logarinho, E. \& Maciel, P. (2011). Absence of ataxin-3 leads to enhanced stress response in C. elegans. PLoS One, Vol. 6, No. 4, pp. e18512, ISSN 1932-6203

Rolfs, A.; Koeppen, A. H.; Bauer, I.; Bauer, P.; Buhlmann, S.; Topka, H.; Schols, L. \& Riess, O. (2003). Clinical features and neuropathology of autosomal dominant spinocerebellar ataxia (SCA17). Ann Neurol, Vol. 54, No. 3, pp. 367-75, ISSN 03645134

Rüb, U.; de Vos, R. A.; Brunt, E. R.; Schultz, C.; Paulson, H.; Del Tredici, K. \& Braak, H. (2002a). Degeneration of the external cuneate nucleus in spinocerebellar ataxia type 3 (Machado-Joseph disease). Brain Res, Vol. 953, No. 1-2, pp. 126-34, ISSN 0006-8993

Rüb, U.; de Vos, R. A.; Schultz, C.; Brunt, E. R.; Paulson, H. \& Braak, H. (2002b). Spinocerebellar ataxia type 3 (Machado-Joseph disease): severe destruction of the lateral reticular nucleus. Brain, Vol. 125, No. Pt 9, pp. 2115-24, ISSN 0006-8950

Rubin, G. M.; Yandell, M. D.; Wortman, J. R.; Gabor Miklos, G. L.; Nelson, C. R.; Hariharan, I. K.; Fortini, M. E.; Li, P. W.; Apweiler, R.; Fleischmann, W.; Cherry, J. M.; Henikoff, S.; Skupski, M. P.; Misra, S.; Ashburner, M.; Birney, E.; Boguski, M. S.; Brody, T.; Brokstein, P.; Celniker, S. E.; Chervitz, S. A.; Coates, D.; Cravchik, A.; Gabrielian, A.; Galle, R. F.; Gelbart, W. M.; George, R. A.; Goldstein, L. S.; Gong, F.; Guan, P.; Harris, N. L.; Hay, B. A.; Hoskins, R. A.; Li, J.; Li, Z.; Hynes, R. O.; Jones, S. J.; Kuehl, P. M.; Lemaitre, B.; Littleton, J. T.; Morrison, D. K.; Mungall, C.; O'Farrell, P. H.; Pickeral, O. K.; Shue, C.; Vosshall, L. B.; Zhang, J.; Zhao, Q.; Zheng, X. H. \& Lewis, S. (2000). Comparative genomics of the eukaryotes. Science, Vol. 287, No. 5461, pp. 2204-15, ISSN 0036-8075

Saegusa, H.; Wakamori, M.; Matsuda, Y.; Wang, J.; Mori, Y.; Zong, S. \& Tanabe, T. (2007). Properties of human Cav2.1 channel with a spinocerebellar ataxia type 6 mutation 
expressed in Purkinje cells. Mol Cell Neurosci, Vol. 34, No. 2, pp. 261-70, ISSN 10447431

Satterfield, T. F.; Jackson, S. M. \& Pallanck, L. J. (2002). A Drosophila homolog of the polyglutamine disease gene SCA2 is a dosage-sensitive regulator of actin filament formation. Genetics, Vol. 162, No. 4, pp. 1687-702, ISSN 0016-6731

Satterfield, T. F. \& Pallanck, L. J. (2006). Ataxin-2 and its Drosophila homolog, ATX2, physically assemble with polyribosomes. Hum Mol Genet, Vol. 15, No. 16, pp. 252332, ISSN 0964-6906

Sayers, E. W.; Barrett, T.; Benson, D. A.; Bolton, E.; Bryant, S. H.; Canese, K.; Chetvernin, V.; Church, D. M.; DiCuccio, M.; Federhen, S.; Feolo, M.; Fingerman, I. M.; Geer, L. Y.; Helmberg, W.; Kapustin, Y.; Landsman, D.; Lipman, D. J.; Lu, Z.; Madden, T. L.; Madej, T.; Maglott, D. R.; Marchler-Bauer, A.; Miller, V.; Mizrachi, I.; Ostell, J.; Panchenko, A.; Phan, L.; Pruitt, K. D.; Schuler, G. D.; Sequeira, E.; Sherry, S. T.; Shumway, M.; Sirotkin, K.; Slotta, D.; Souvorov, A.; Starchenko, G.; Tatusova, T. A.; Wagner, L.; Wang, Y.; Wilbur, W. J.; Yaschenko, E. \& Ye, J. (2011). Database resources of the National Center for Biotechnology Information. Nucleic Acids Res, Vol. 39, No. Database issue, pp. D38-51, ISSN 1362-4962

Schmidt, T.; Lindenberg, K. S.; Krebs, A.; Schöls, L.; Laccone, F.; Herms, J.; Rechsteiner, M.; Riess, O. \& Landwehrmeyer, G. B. (2002). Protein surveillance machinery in brains with spinocerebellar ataxia type 3: redistribution and differential recruitment of $26 \mathrm{~S}$ proteasome subunits and chaperones to neuronal intranuclear inclusions. Ann Neurol, Vol. 51, No. 3, pp. 302-10, ISSN 0364-5134

Schmitt, I.; Linden, M.; Khazneh, H.; Evert, B. O.; Breuer, P.; Klockgether, T. \& Wuellner, U. (2007). Inactivation of the mouse Atxn3 (ataxin-3) gene increases protein ubiquitination. Biochem Biophys Res Commun, Vol. 362, No. 3, pp. 734-9, ISSN 0006291X

Schöls, L.; Bauer, P.; Schmidt, T.; Schulte, T. \& Riess, O. (2004). Autosomal dominant cerebellar ataxias: clinical features, genetics, and pathogenesis. Lancet Neurol, Vol. 3, No. 5, pp. 291-304, ISSN 1474-4422

Shah, A. G.; Friedman, M. J.; Huang, S.; Roberts, M.; Li, X. J. \& Li, S. (2009). Transcriptional dysregulation of TrkA associates with neurodegeneration in spinocerebellar ataxia type 17. Hum Mol Genet, Vol. 18, No. 21, pp. 4141-52, ISSN 1460-2083

Silva-Fernandes, A.; Costa Mdo, C.; Duarte-Silva, S.; Oliveira, P.; Botelho, C. M.; Martins, L.; Mariz, J. A.; Ferreira, T.; Ribeiro, F.; Correia-Neves, M.; Costa, C. \& Maciel, P. (2010). Motor uncoordination and neuropathology in a transgenic mouse model of Machado-Joseph disease lacking intranuclear inclusions and ataxin-3 cleavage products. Neurobiol Dis, Vol. 40, No. 1, pp. 163-76, ISSN 1095-953X

Switonski, P. M.; Fiszer, A.; Kazmierska, K.; Kurpisz, M.; Krzyzosiak, W. J. \& Figiel, M. (2011). Mouse ataxin-3 functional knock-out model. Neuromolecular Med, Vol. 13, No. 1, pp. 54-65, ISSN 1559-1174

Teixeira-Castro, A.; Ailion, M.; Jalles, A.; Brignull, H. R.; Vilaca, J. L.; Dias, N.; Rodrigues, P.; Oliveira, J. F.; Neves-Carvalho, A.; Morimoto, R. I. \& Maciel, P. (2011). Neuronspecific proteotoxicity of mutant ataxin-3 in C. elegans: rescue by the DAF-16 and HSF-1 pathways. Hum Mol Genet, Vol. 20, No. 15, pp. 2996-3009, ISSN 1460-2083

Tsuda, H.; Jafar-Nejad, H.; Patel, A. J.; Sun, Y.; Chen, H. K.; Rose, M. F.; Venken, K. J.; Botas, J.; Orr, H. T.; Bellen, H. J. \& Zoghbi, H. Y. (2005). The AXH domain of Ataxin-1 
mediates neurodegeneration through its interaction with Gfi-1/Senseless proteins. Cell, Vol. 122, No. 4, pp. 633-44, ISSN 0092-8674

van de Leemput, J.; Chandran, J.; Knight, M. A.; Holtzclaw, L. A.; Scholz, S.; Cookson, M. R.; Houlden, H.; Gwinn-Hardy, K.; Fung, H. C.; Lin, X.; Hernandez, D.; SimonSanchez, J.; Wood, N. W.; Giunti, P.; Rafferty, I.; Hardy, J.; Storey, E.; Gardner, R. J.; Forrest, S. M.; Fisher, E. M.; Russell, J. T.; Cai, H. \& Singleton, A. B. (2007). Deletion at ITPR1 underlies ataxia in mice and spinocerebellar ataxia 15 in humans. PLoS Genet, Vol. 3, No. 6, pp. e108, ISSN 1553-7404

van de Warrenburg, B. P.; Frenken, C. W.; Ausems, M. G.; Kleefstra, T.; Sinke, R. J.; Knoers, N. V. \& Kremer, H. P. (2001). Striking anticipation in spinocerebellar ataxia type 7: the infantile phenotype. J Neurol, Vol. 248, No. 10, pp. 911-4, ISSN 0340-5354

Vandaele, S.; Nordquist, D. T.; Feddersen, R. M.; Tretjakoff, I.; Peterson, A. C. \& Orr, H. T. (1991). Purkinje cell protein-2 regulatory regions and transgene expression in cerebellar compartments. Genes Dev, Vol. 5, No. 7, pp. 1136-48, ISSN 0890-9369

Vig, P. J.; Subramony, S. H.; D'Souza, D. R.; Wei, J. \& Lopez, M. E. (2006). Intranasal administration of IGF-I improves behavior and Purkinje cell pathology in SCA1 mice. Brain Res Bull, Vol. 69, No. 5, pp. 573-9, ISSN 0361-9230

Voisine, C.; Varma, H.; Walker, N.; Bates, E. A.; Stockwell, B. R. \& Hart, A. C. (2007). Identification of potential therapeutic drugs for huntington's disease using Caenorhabditis elegans. PLoS One, Vol. 2, No. 6, pp. e504, ISSN 1932-6203

Warrick, J. M.; Morabito, L. M.; Bilen, J.; Gordesky-Gold, B.; Faust, L. Z.; Paulson, H. L. \& Bonini, N. M. (2005). Ataxin-3 suppresses polyglutamine neurodegeneration in Drosophila by a ubiquitin-associated mechanism. Mol Cell, Vol. 18, No. 1, pp. 37-48, ISSN 1097-2765

Warrick, J. M.; Paulson, H. L.; Gray-Board, G. L.; Bui, Q. T.; Fischbeck, K. H.; Pittman, R. N. \& Bonini, N. M. (1998). Expanded polyglutamine protein forms nuclear inclusions and causes neural degeneration in Drosophila. Cell, Vol. 93, No. 6, pp. 939-49, ISSN 0092-8674

Watase, K.; Barrett, C. F.; Miyazaki, T.; Ishiguro, T.; Ishikawa, K.; Hu, Y.; Unno, T.; Sun, Y.; Kasai, S.; Watanabe, M.; Gomez, C. M.; Mizusawa, H.; Tsien, R. W. \& Zoghbi, H. Y. (2008). Spinocerebellar ataxia type 6 knockin mice develop a progressive neuronal dysfunction with age-dependent accumulation of mutant CaV2.1 channels. Proc Natl Acad Sci U S A, Vol. 105, No. 33, pp. 11987-92, ISSN 1091-6490

Watase, K.; Gatchel, J. R.; Sun, Y.; Emamian, E.; Atkinson, R.; Richman, R.; Mizusawa, H.; Orr, H. T.; Shaw, C. \& Zoghbi, H. Y. (2007). Lithium therapy improves neurological function and hippocampal dendritic arborization in a spinocerebellar ataxia type 1 mouse model. PLoS Med, Vol. 4, No. 5, pp. e182, ISSN 1549-1676

Watase, K.; Venken, K. J.; Sun, Y.; Orr, H. T. \& Zoghbi, H. Y. (2003). Regional differences of somatic CAG repeat instability do not account for selective neuronal vulnerability in a knock-in mouse model of SCA1. Hum Mol Genet, Vol. 12, No. 21, pp. 2789-95, ISSN 0964-6906

Watase, K.; Weeber, E. J.; Xu, B.; Antalffy, B.; Yuva-Paylor, L.; Hashimoto, K.; Kano, M.; Atkinson, R.; Sun, Y.; Armstrong, D. L.; Sweatt, J. D.; Orr, H. T.; Paylor, R. \& Zoghbi, H. Y. (2002). A long CAG repeat in the mouse Sca1 locus replicates SCA1 features and reveals the impact of protein solubility on selective neurodegeneration. Neuron, Vol. 34, No. 6, pp. 905-19, ISSN 0896-6273 
Xia, H.; Mao, Q.; Eliason, S. L.; Harper, S. Q.; Martins, I. H.; Orr, H. T.; Paulson, H. L.; Yang, L.; Kotin, R. M. \& Davidson, B. L. (2004). RNAi suppresses polyglutamine-induced neurodegeneration in a model of spinocerebellar ataxia. Nat Med, Vol. 10, No. 8, pp. 816-20, ISSN 1078-8956

Yoo, S. Y.; Pennesi, M. E.; Weeber, E. J.; Xu, B.; Atkinson, R.; Chen, S.; Armstrong, D. L.; Wu, S. M.; Sweatt, J. D. \& Zoghbi, H. Y. (2003). SCA7 knockin mice model human SCA7 and reveal gradual accumulation of mutant ataxin-7 in neurons and abnormalities in short-term plasticity. Neuron, Vol. 37, No. 3, pp. 383-401, ISSN 0896-6273

Yvert, G.; Lindenberg, K. S.; Picaud, S.; Landwehrmeyer, G. B.; Sahel, J. A. \& Mandel, J. L. (2000). Expanded polyglutamines induce neurodegeneration and trans-neuronal alterations in cerebellum and retina of SCA7 transgenic mice. Hum Mol Genet, Vol. 9, No. 17, pp. 2491-506, ISSN 0964-6906

Zoghbi, H. Y. \& Botas, J. (2002). Mouse and fly models of neurodegeneration. Trends Genet, Vol. 18, No. 9, pp. 463-71, ISSN 0168-9525

Zu, T.; Duvick, L. A.; Kaytor, M. D.; Berlinger, M. S.; Zoghbi, H. Y.; Clark, H. B. \& Orr, H. T. (2004). Recovery from polyglutamine-induced neurodegeneration in conditional SCA1 transgenic mice. J Neurosci, Vol. 24, No. 40, pp. 8853-61, ISSN 1529-2401 


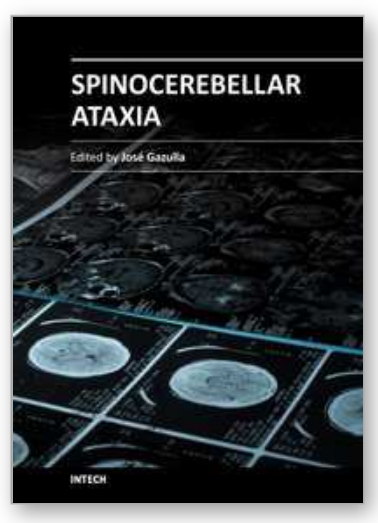

\author{
Spinocerebellar Ataxia \\ Edited by Dr. José Gazulla
}

ISBN 978-953-51-0542-8

Hard cover, 198 pages

Publisher InTech

Published online 18, April, 2012

Published in print edition April, 2012

The purpose of this book has been to depict as many biochemical, genetic and molecular advances as possible, in the vast field of the spinocerebellar ataxias.

\title{
How to reference
}

In order to correctly reference this scholarly work, feel free to copy and paste the following:

Thorsten Schmidt, Jana Schmidt and Jeannette Hübener (2012). Model Systems for Spinocerebellar Ataxias: Lessons Learned About the Pathogenesis, Spinocerebellar Ataxia, Dr. José Gazulla (Ed.), ISBN: 978-953-510542-8, InTech, Available from: http://www.intechopen.com/books/spinocerebellar-ataxia/model-systems-forspinocerebellar-ataxias-lessons-learned-about-the-pathogenesis

\section{INTECH}

open science | open minds

\section{InTech Europe}

University Campus STeP Ri

Slavka Krautzeka 83/A

51000 Rijeka, Croatia

Phone: +385 (51) 770447

Fax: +385 (51) 686166

www.intechopen.com

\section{InTech China}

Unit 405, Office Block, Hotel Equatorial Shanghai

No.65, Yan An Road (West), Shanghai, 200040, China 中国上海市延安西路65号上海国际贵都大饭店办公楼 405 单元

Phone: +86-21-62489820

Fax: $+86-21-62489821$ 
(C) 2012 The Author(s). Licensee IntechOpen. This is an open access article distributed under the terms of the Creative Commons Attribution 3.0 License, which permits unrestricted use, distribution, and reproduction in any medium, provided the original work is properly cited. 